\title{
ГИДРОЛОГО-ГИДРОХИМИЧЕСКИЕ И ГИДРОБИОЛОГИЧЕСКИЕ ИССЛЕДОВАНИЯ НА КАРАДАГСКОМ ВЗМОРЬЕ В ТЕПЛЫЙ ПЕРИОД 2016 Г.
}

\author{
Ковригина Н.П., Трощенко О.А., Лисицкая Е.В., Поспелова Н.В., Еремин И.Ю. \\ Институт морских биологических исследований им. А.О. Ковалевского РАН, \\ 2. Севастополь, Российская Федерация, e-mail: maricultura@mail.ru
}

Приведены результаты комплексных исследований, проведенных в мае и сентябре 2016 г. в прибрежной акватории Карадага и в Коктебельской бухте. Представлены данные по термохалинной структуре вод, гидрохимическим показателям (содержанию растворенного кислорода, окисляемости, БПК 5 и основных биогенных элементов), численности и биомассе фитои меропланктона. Показано, что термохалинная структура непосредственно влияет на распределение гидрохимических и гидробиологических показателей. Отмечено присутствие азовоморских вод на поверхности и субмаринной разгрузки в придонном слое исследуемой акватории. Установлено влияние хозбытовых стоков поселков Коктебель и Курортное на распределение гидрологических и гидрохимических полей, а также на состояние фито- и меропланктона. Проведено сравнение величин содержания органического вещества и численности меропланктона, полученных нами в начале исследований (2004 г.) с материалами 2016 г. Показана связь между значениями суммарной численности и биомассы фитопланктона с биогенными веществами.

Ключевые слова: гидролого-гидрохимическая структура, биогенные элементы, фитопланктон, меропланктон, прибрежная зона Карадага, Черное море.

\section{Введение}

Комплексные гидролого-гидрохимические и гидробиологические исследования в районе Карадага на современном этапе (2004 - 2016 гг.) были вызваны необходимостью изучения экологического состояния прибрежной зоны, которая с давних пор считалась «чистой», т.е. в наименьшей степени подверженной антропогенному воздействию. Однако сброс хозбытовых сточных вод от поселков Курортное и Коктебель, сток реки Отузки, ливневые и дренажные воды, поступающие в узкую прибрежную зону, изменяют ее гидролого-гидрохимическую структуру. Существенную роль в этом играют опресненные воды, поступающие из Азовского моря, а также пресные воды подземного происхождения (Ковригина, Трощенко, Щуров, 2009). В то же время, гидрохимические условия среды и гидродинамика вод влияют на видовой состав, численность и биомассу фито- и меропланктона (Ковригина и др., 2007).

Фитопланктон в изучаемом районе представлен микроводорослями, относящимися к различным экологическим группам. Отмечено более высокое количественное развитие планктонных водорослей в начале 21 столетия, по сравнению с 20 -ым, а также изменение состава доминирующих видов (Костенко, 2015; Сеничева, Поспелова, 2015). На современном этапе исследований наблюдаются вспышки развития мелкоклеточных водорослей - кокколитофорид, зелёных водорослей и цианобактерий на фоне повышенного содержания биогенных и органических веществ. На видовой состав и численность фитопланктона в районе Карадага влияют также сгонно-нагонные явления, распреснённые азовоморские воды и хозбытовые стоки (Сеничева, Поспелова, 2015).

В состав меропланктона входят пелагические личинки донных беспозвоночных, которые находятся в толще воды только на ранних стадиях развития, затем оседают и переходят к другому образу жизни. Изучая таксономический состав и численность 
меропланктона можно косвенно судить о сроках и интенсивности размножения гидробионтов, о состоянии их популяций в районе исследования. Повышенное содержание органического вещества в сточных водах негативно отражается на численности меропланктона (Ковригина и др., 2007; Павлова, Лисицкая, 2009).

Целью настоящей работы является выявление особенностей изменчивости некоторых гидролого-гидрохимических и биологических параметров в акватории Карадагского природного заповедника и в Коктебельской бухте, а также оценка антропогенного влияния на ее узкую прибрежную зону по материалам, полученным в теплый период 2016 г.

\section{Материалы и методы}

В 2016 г. в прибрежной зоне Карадага проведены две комплексные съемки: 27 мая и 7 сентября. Пробы отбирались на четырех разрезах по нормали к береговой линии - от причала бухты Коктебель, от мыса Мальчин, от бухты Сердоликовой и от Биостанции. Кроме разрезов пробы отбирали на двух прибрежных станциях в районах стока реки Отузки и очистных сооружений поселка Курортное. Схема станций отбора проб не изменялась с 2012 г. (рис. 1).

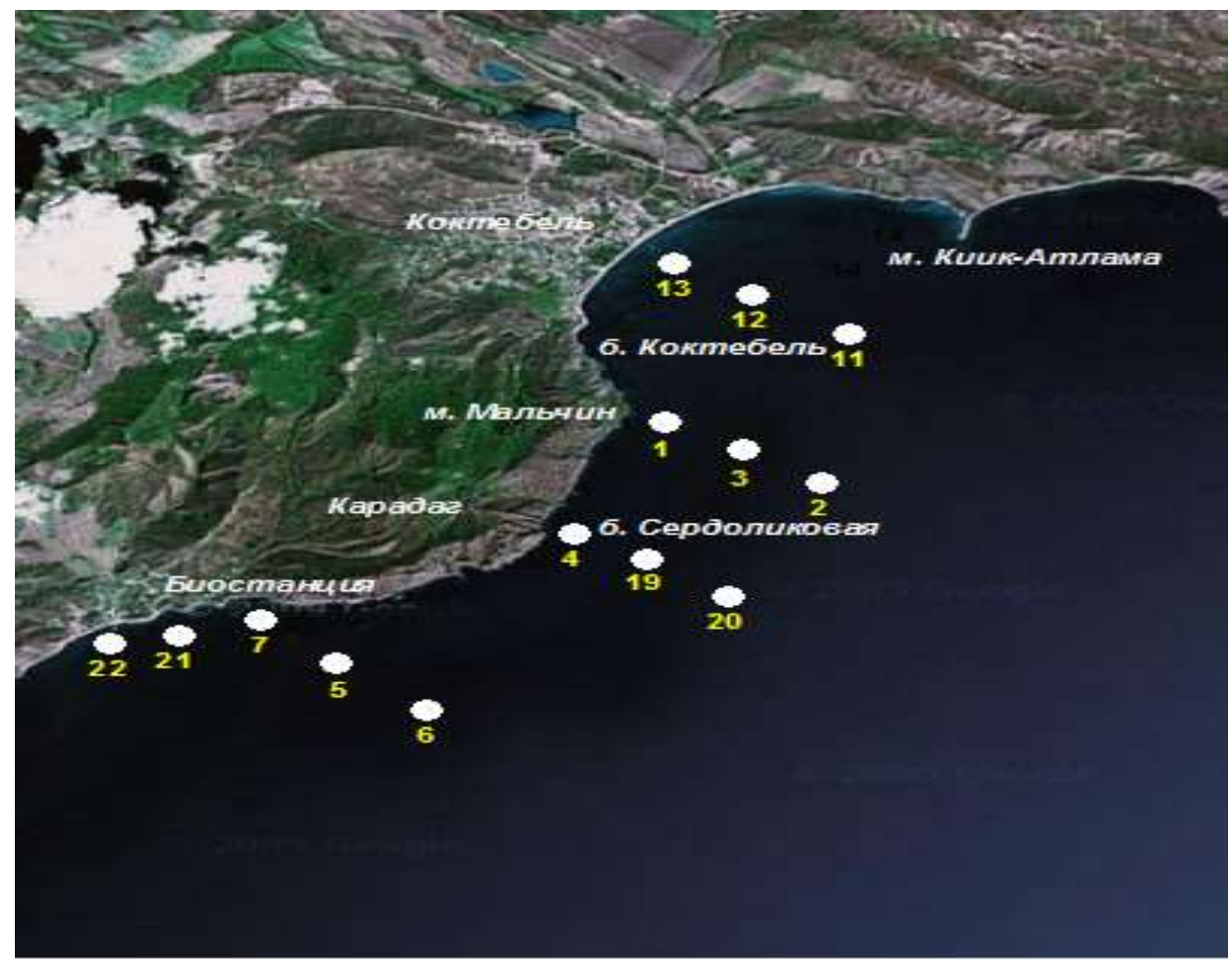

Pис. 1. Схема станций отбора проб на Карадагском взморье в 2016 г.

В комплекс гидролого-гидрохимических исследований входило измерение температуры, солености, растворенного кислорода, биохимического потребления кислорода на пятые сутки (БПК $)$, перманганатной окисляемости в щелочной среде, кремния, органических и неорганических форм азота и фосфора. Гидрохимические пробы отбирали на всех станциях с поверхности и у дна. Всего отобрано 56 проб и выполнено около 570 гидролого-гидрохимических анализов, проведенных согласно общепринятым методикам (Методы гидрохимических исследований, 1988; Методические указания №30, 1966; Руководство по гидрологическим работам, 1977). По величинам окисляемости 
рассчитано содержание органического углерода (Сров) на поверхности в прибрежной зоне Карадагского природного заповедника и в Коктебельской бухте (Скопинцев, 1975).

Гидробиологические исследования включали изучение таксономического состава, численности и биомассы фито- и меропланктона на прибрежных станциях. Пробы фитопланктона объемом $1-1.5$ л отбирали с поверхности шести станций $(1,4,7,13,21$, 22) и концентрировали методом обратной фильтрации с использованием ядерных (трековых) мембран ( $\mathrm{D}_{\text {пор }}=1$ мкм) до объема $30-40$ мл, фиксировали раствором Люголя и обрабатывали под световым микроскопом Jenaval. Учет мелких видов проводили в живой и сгущенной капле 0.01 мл, крупноклеточные виды учитывали в камере $(\mathrm{V}=0.8$ мл). Численность и биомассу фитопланктона рассчитывали с помощью компьютерной программы Plankton.

Меропланктон собирали сетью Джеди (диаметр входного отверстия 36 см, размер ячеи мельничного газа 135 мкм) на станциях $1,4,7,13$. Облавливали весь слой воды $10-$ 0 м. Первичную обработку выполняли на живом материале путём тотального подсчёта пелагических личинок донных беспозвоночных в камере Богорова под бинокуляром МБС9. Для дальнейшей идентификации личинок фиксировали 4\% раствором формалина. Для уточнения видовой принадлежности использовали световой микроскоп Микмед-5. Всего отобрано 20 гидробиологических проб. Обработка гидролого-гидрохимического и гидробиологического материала выполнена в отделе аквакультуры и морской фармакологии ФГБУН ИМБИ РАН.

\section{Результаты и обсуждение}

Съемка 27 мая 2016 г.

Во время съемки диапазон изменчивости поверхностной температуры был достаточно широким для этого района: $16.2^{\circ}-17.6^{\circ} \mathrm{C}$ (рис. 2 , табл. 1$)$.

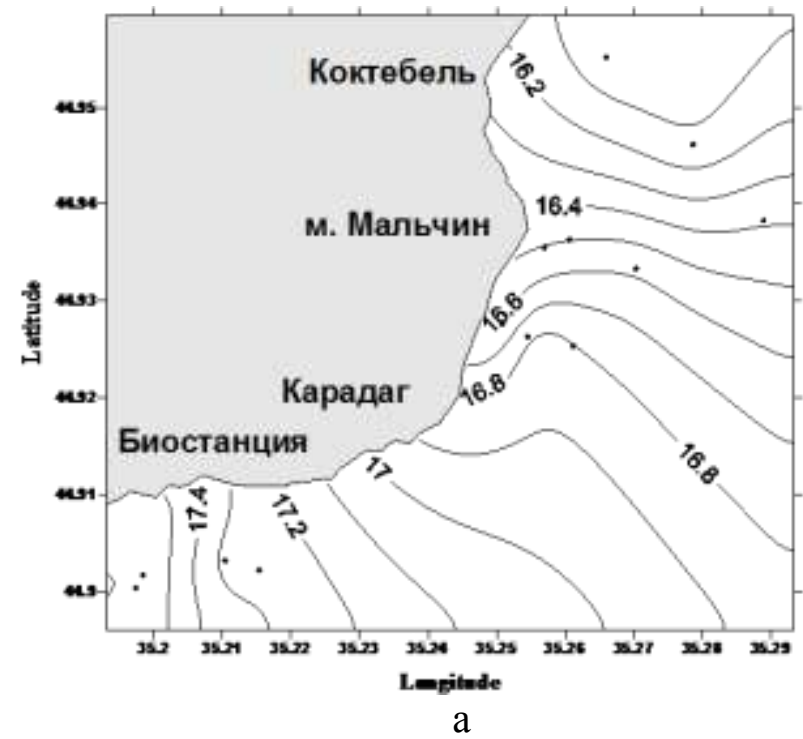

Рис. 2. Распределение поверхностной температуры

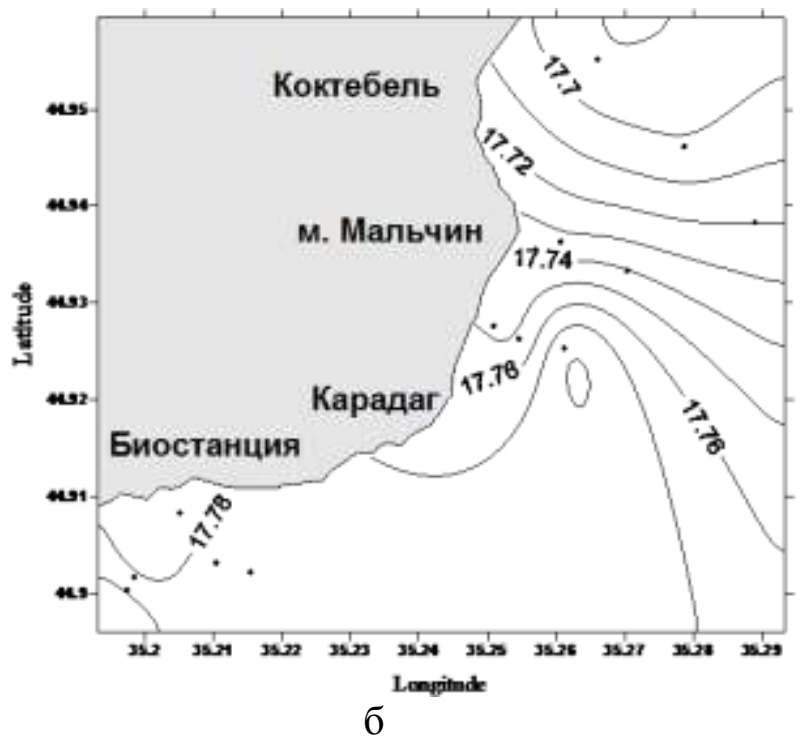

(а) и солёности (б) 27 мая 2016 г.

Полученные значения температур были выше среднемноголетних показателей для мая и больше соответствовали среднеиюньским характеристикам (Трощенко, Субботин, Ерёмин, 2015). В целом, температура плавно повышалась от Коктебельской бухты к п. Курортное. Некоторое сгущение изотерм наблюдалось в районе мыса Мальчин. Вертикальная термическая структура была типична для этого периода года. В 
поверхностном слое сформировался верхний квазиоднородный слой (ВКС). Его мощность незначительна - от 2 до 4 м. Глубже располагался сезонный термоклин (СТ). Градиенты в нём, в среднем, составляли около $0.1^{\circ} \mathrm{C} / \mathrm{M}$. Интересная особенность данной съёмки состояла в том, что ядро СТ (слой максимальных градиентов) располагалось не в подповерхностном слое, как обычно, а на придонных горизонтах удалённых от берега станций.

Диапазон изменчивости поверхностной солёности был незначительным - 17.69$17.79 \%$. Солёность, как и температура, повышалась от Коктебельской бухты к п. Курортное. Также в районе м. Мальчин наблюдалось сгущение изохалин. При этом фронтальная зона по солёности выражена более значимо, чем по температуре. Формирование гидрологического фронта в районе м. Мальчин должно отразиться на распределении гидрохимических и гидробиологических характеристик, о чём будет сказано ниже. С глубиной солёность незначительно повышалась. Относительно большие вертикальные градиенты солёности наблюдались на мелководных прибрежных станциях в п. Курортное - до $0.1 \%$ /м (табл. 1). Это очевидно связано с поверхностным стоком.

Таблица 1.

Распределение гидролого-гидрохимических показателей на Карадагском взморье.

\begin{tabular}{|c|c|c|c|c|c|c|c|c|c|c|c|c|c|c|}
\hline \multicolumn{15}{|c|}{ Карадагское взморье. Коктебель. Разрезы. 27 мая 2016 г. } \\
\hline № & \multirow{2}{*}{$\begin{array}{l}\mathrm{H}, \\
\mathrm{M}\end{array}$} & \multirow{2}{*}{$\begin{array}{l}\mathrm{T}, \\
{ }^{\circ} \mathrm{C}\end{array}$} & \multirow{2}{*}{$\begin{array}{l}\mathrm{S} \\
\%\end{array}$} & \multicolumn{2}{|c|}{$\mathrm{O}_{2}$} & \multirow{2}{*}{$\begin{array}{c}\text { БПК }{ }_{5}, \\
\text { мГ/Л }\end{array}$} & $\mathrm{NO}_{2}$ & $\mathrm{NO}_{3}$, & $\mathrm{NH}_{4}$, & $\mathrm{PO}_{4}$, & $\mathrm{Si}$ & Рорг & Nopг & \multirow{2}{*}{$\begin{array}{l}\text { Окис } \\
\text { мгО/л }\end{array}$} \\
\hline ст & & & & мл/л & $\%$ & & \multicolumn{7}{|c|}{ мкт/л } & \\
\hline 13 & 0 & 16,20 & 17,69 & 6,52 & 105,6 & 2,28 & 0,9 & 2,4 & & 3,2 & 97,0 & 8,3 & 365 & 3,06 \\
\hline 13 & 10 & 15,60 & 18,05 & 6,62 & 106,1 & & 0,0 & 2,3 & & 4,9 & 75,9 & & & \\
\hline 12 & 0 & 16,40 & 17,70 & 6,57 & 106,8 & 1,58 & 0,4 & 2,2 & & 5,3 & 79,2 & 6,9 & 439 & 3,08 \\
\hline 12 & 20 & 14,60 & 18,02 & 6,73 & 105,6 & & 1,1 & 0,9 & & 6,7 & 81,8 & & & \\
\hline 11 & 0 & 16,40 & 17,72 & 6,74 & 109,6 & 1,80 & 0,4 & 3,0 & & 6,7 & 71,3 & 2,9 & 308 & 2,99 \\
\hline 11 & 30 & 12,60 & 18,04 & 7,13 & 107,2 & & & & & & & & & \\
\hline 2 & 0 & 16,60 & 17,74 & 6,54 & 106,9 & 1,30 & 0,4 & 2,1 & & 3,5 & 60,7 & 5,7 & 313 & 3,33 \\
\hline 2 & 29 & 12,90 & 18,05 & 6,94 & 105,1 & & 0,3 & 2,0 & & 3,9 & 99,0 & & & \\
\hline 3 & 0 & 16,50 & 17,73 & 6,57 & 107,1 & 1,55 & 0,1 & 2,0 & & 4,9 & 59,4 & 10,2 & 387 & 4,71 \\
\hline 3 & 20 & 14,20 & 18,03 & 6,66 & 103,6 & & 0,2 & 3,1 & & 4,9 & 125,4 & & & \\
\hline 1 & 0 & 16,50 & 17,74 & 6,63 & 108,0 & 1,94 & 0,2 & 0,8 & & 2,8 & 74,6 & 8,2 & 347 & 3,41 \\
\hline 1 & 12 & 16,00 & 18,06 & 6,64 & 107,3 & & 0,2 & 1,5 & & 2,5 & 40,9 & & & \\
\hline 4 & 0 & 16,50 & 17,75 & 6,76 & 110,2 & 2,12 & 0,1 & 2,2 & & 2,5 & 81,1 & 7,1 & 374 & 2,91 \\
\hline 4 & 10 & 15,50 & 18,02 & 6,62 & 105,8 & & 0,3 & 3,9 & & 2,8 & 79,8 & & & \\
\hline 19 & 0 & 16,90 & 17,74 & 6,45 & 105,9 & 1,37 & 0,1 & 2,4 & & 2,5 & 125,4 & 8,2 & 435 & 4,41 \\
\hline 19 & 20 & 14,80 & 18,03 & 6,71 & 105,8 & & 0,4 & 4,6 & & 3,2 & 110,2 & & & \\
\hline 20 & 0 & 16,80 & 17,79 & 6,51 & 106,8 & 0,79 & 0,1 & 2,0 & & 2,8 & 67,3 & 6,4 & 354 & 2,55 \\
\hline 20 & 30 & 12,10 & 18,08 & 6,94 & 103,3 & & 0,5 & 1,7 & & 4,9 & 138,5 & & & \\
\hline 6 & 0 & 17,30 & 17,79 & 6,75 & 111,9 & 1,56 & 0,1 & 1,6 & & 3,2 & 92,4 & 7,5 & 302 & 2,60 \\
\hline 6 & 30 & 12,20 & 18,04 & 7,05 & 105,1 & & 0,1 & 2,3 & & 3,5 & 129,3 & & & \\
\hline 5 & 0 & 17,20 & 17,77 & 6,47 & 107,0 & 0,84 & 0,1 & 1,5 & & 3,5 & 105,6 & 6,8 & 330 & 3,26 \\
\hline 5 & 20 & 14,00 & 18,04 & 6,75 & 104,7 & & 0,4 & 1,9 & & 4,2 & 83,8 & & & \\
\hline 7 & 0 & 17,50 & 17,78 & 6,42 & 106,8 & 1,21 & 0,5 & 2,1 & & 3,9 & 105,6 & 25,2 & 483 & 2,41 \\
\hline 7 & 8 & 16,30 & 18,02 & 6,86 & 111,6 & & 0,4 & 2,2 & & 4,2 & 74,6 & & & \\
\hline 21 & 0 & 17,60 & 17,76 & 6,50 & 108,3 & 1,73 & 0,4 & 1,3 & & 4,9 & 97,6 & 15,7 & 468 & 2,86 \\
\hline 21 & 3 & 17,40 & 18,02 & 6,71 & 111,5 & & 0,4 & 2,2 & & 4,2 & 74,6 & & & \\
\hline 22 & 0 & 17,60 & 17,79 & 6,56 & 109,3 & 0,97 & 0,4 & 1,7 & & 4,2 & 145,1 & 18,6 & 415 & 2,66 \\
\hline 22 & 4 & 17,30 & 18,02 & 6,58 & 109,2 & & 0,4 & 7,0 & & 4,2 & 95,0 & & & \\
\hline
\end{tabular}


Величины растворенного кислорода на всей исследуемой акватории имели высокие значения насыщения, которые были выше нормального на 3-12\%. Средние величины насыщения кислородом на поверхности и у дна мало отличались друг от друга. На поверхности их значения составляли $107.9 \%$, у дна $-106.6 \%$. В придонном слое на разрезах от м. Мальчин (ст. 3 и ст. 2) и Биостанции (ст. 6) отмечено понижение величин насыщения по сравнению с поверхностью на 6, 2 и 4\% соответственно. Одновременно на этих станциях в придонном слое зафиксировано резкое увеличение концентрации кремния. Такая картина распределения кислорода и кремния позволяет говорить о влиянии источников пресных вод подземного происхождения в этих районах (рис. 3).
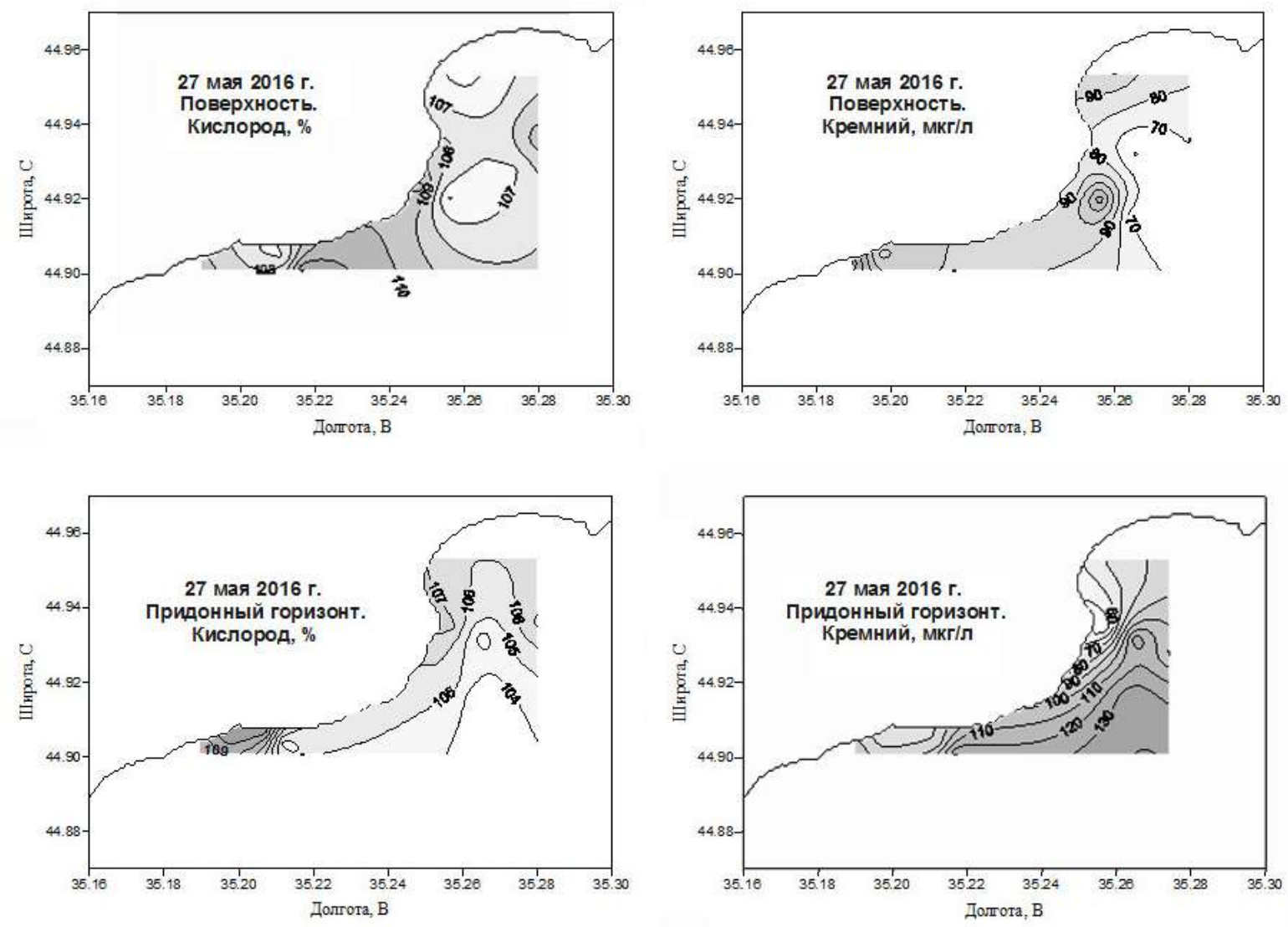

Рис. 3. Распределение кислорода (\%) и кремния (мкг/л) 27 мая 2016 г.

Величины БПК 5 на поверхности изменялись в пределах от 0.79 до 2.28 мг/л. Превышение предельно-допустимой концентрации (ПДК) наблюдали в двух районах: на прибрежной станции 13 в бухте Коктебель $(2.28$ мг/л) и на прибрежной станции 4 в Сердоликовой бухте (2.12 мг/л). Величины окисляемости на этих станциях приближались к средней по съемке величине, равной 3.16 мгО/л. Максимальная величина (4.71 мгО/л) окисляемости отмечена в районе м. Мальчин (ст. 3), несколько ниже значение окисляемости (4.41 мгО/л) - в Сердоликовой бухте (ст. 19). Указанные два значения превышали ПДК, равную 4.0 мгО/л (рис. 4).

Коэффициент загрязнения Кз, рассчитанный по Скопинцеву как отношение БПК 5 окисляемости, изменялся в интервале от 0.26 до 0.73 и не превышал 1. Районы, где были отмечены высокие величины Кз, совпадали с районами, где величины БПК 5 превышали ПДК. Но поскольку на всей акватории Кз был < 1, по санитарно-химическим показателям акваторию можно считать незагрязненной. 

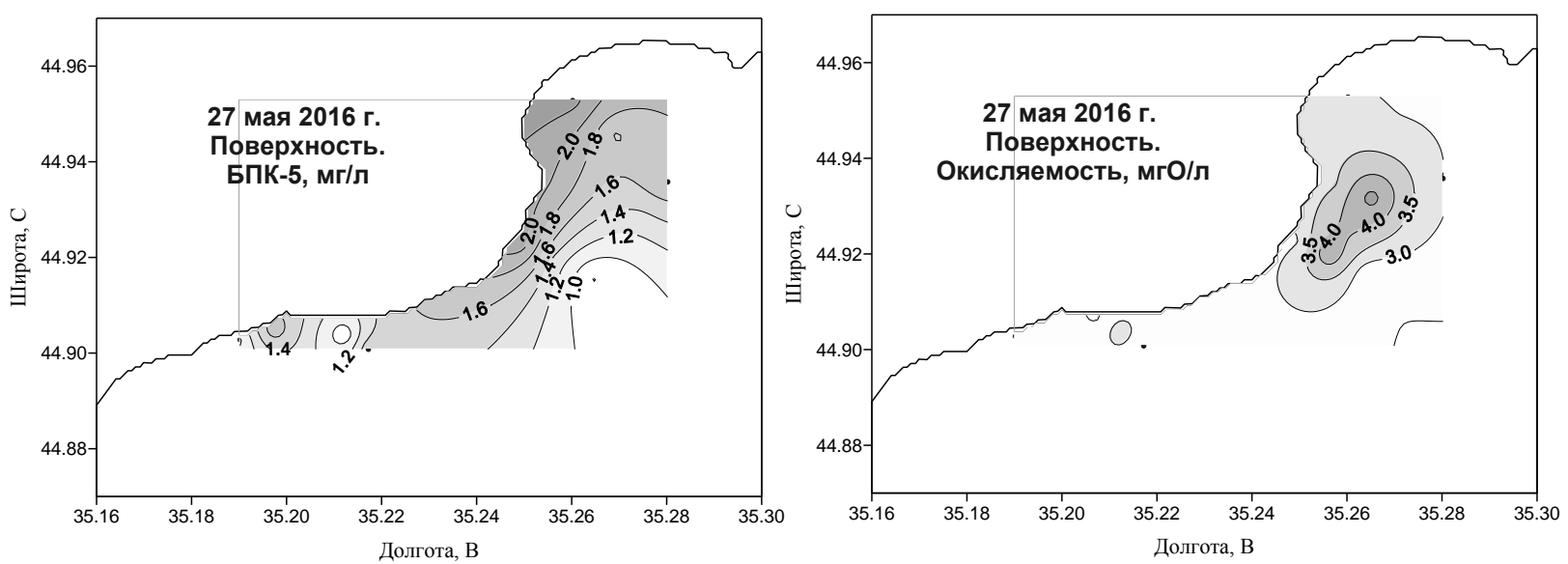

Рис. 4. Распределение величин БПК 5 (мг/л) и окисляемости (мГО/л) 27 мая 2016 г.

Содержание растворенного органического вещества Сров, рассчитанное по величинам окисляемости, изменялось на поверхности от 7.09 до 13.85 мг С/л при среднем значении 9.29 мг С/л (табл. 2).

Таблица 2.

Содержание растворенного органического вещества (Сров) 27.05.2016 г.

\begin{tabular}{|c|c|c|c|c|c|}
\hline N станции & $\begin{array}{c}\text { Окисляемость, } \\
\text { мгО/л }\end{array}$ & $\begin{array}{c}\text { Сров, } \\
\text { мгС/л }\end{array}$ & N станции & $\begin{array}{c}\text { Окисляемость, } \\
\text { мгО/л }\end{array}$ & $\begin{array}{c}\text { Сров, } \\
\text { мгС/л }\end{array}$ \\
\hline 13 & 3.06 & 9.00 & 19 & 4.41 & 12.97 \\
\hline 12 & 3.08 & 9.06 & 20 & 2.55 & 7.50 \\
\hline 11 & 2.99 & 8.79 & 6 & 2.60 & 7.65 \\
\hline 2 & 3.33 & 9.79 & 5 & 3.26 & 9.59 \\
\hline 3 & 4.71 & 13.85 & 7 & 2.41 & 7.09 \\
\hline 1 & 3.41 & 10.03 & 21 & 2.86 & 8.41 \\
\hline 4 & 2.91 & 8.56 & 22 & 2.66 & 7.82 \\
\hline
\end{tabular}

Минимальное содержание растворенного органического вещества отмечено в районе Биостанции, максимальное - в районе м. Мальчин. По сравнению с началом исследований (июль 2004 г.) величины Сров в районах м. Мальчин и б. Сердоликовая в 2016 г. немного повысились, а в районе Биостанции - понизилось.

Биогенные вещества имели однородные и низкие концентрации. Величины нитритного азота во всем исследуемом слое колебались в пределах от 0 до 0.9 мкг/л, нитратного - от 0.9 до 7,0 мкг/л, минерального фосфора - от 2.5 до 6.7 и кремния - от 41 до 145 мкг/л (рис. 5).

По повышенным концентрациям фосфатов на прибрежных станциях прослежено влияние хозбытовых стоков в районе Биостанции, стока р. Отузки и Очистных. Так, на ст. 7 концентрация фосфатов составила 3.9 мкг/л, на ст. 21 - 4.9 мкг/л и на ст. 22 - 4.2 мкг/л. Кроме того, на поверхности этих же станций наблюдали повышенное содержание фосфора органического: 25.2 мкг/л (ст. 7), 15.7 мкг/л (ст. 21) и 18.6 мкг/л (ст. 22). Подтверждением влияния хозбытовых стоков в этих районах являются также высокие величины органического азота, полученные на поверхности ст. 7 (483 мкг/л), 21 (468 мкг/л) и 22 (415 мкг/л).

Максимальная концентрация фосфатов (6.7 мкг/л), зафиксированная на мористой станции в Коктебельской бухте, свидетельствует о возможном влиянии азовоморских вод. Кроме того, средняя концентрация фосфатов на поверхности Коктебельской бухты (5.1 мкг/л) была выше, чем на акватории Карадага (3.7 мкг/л). 

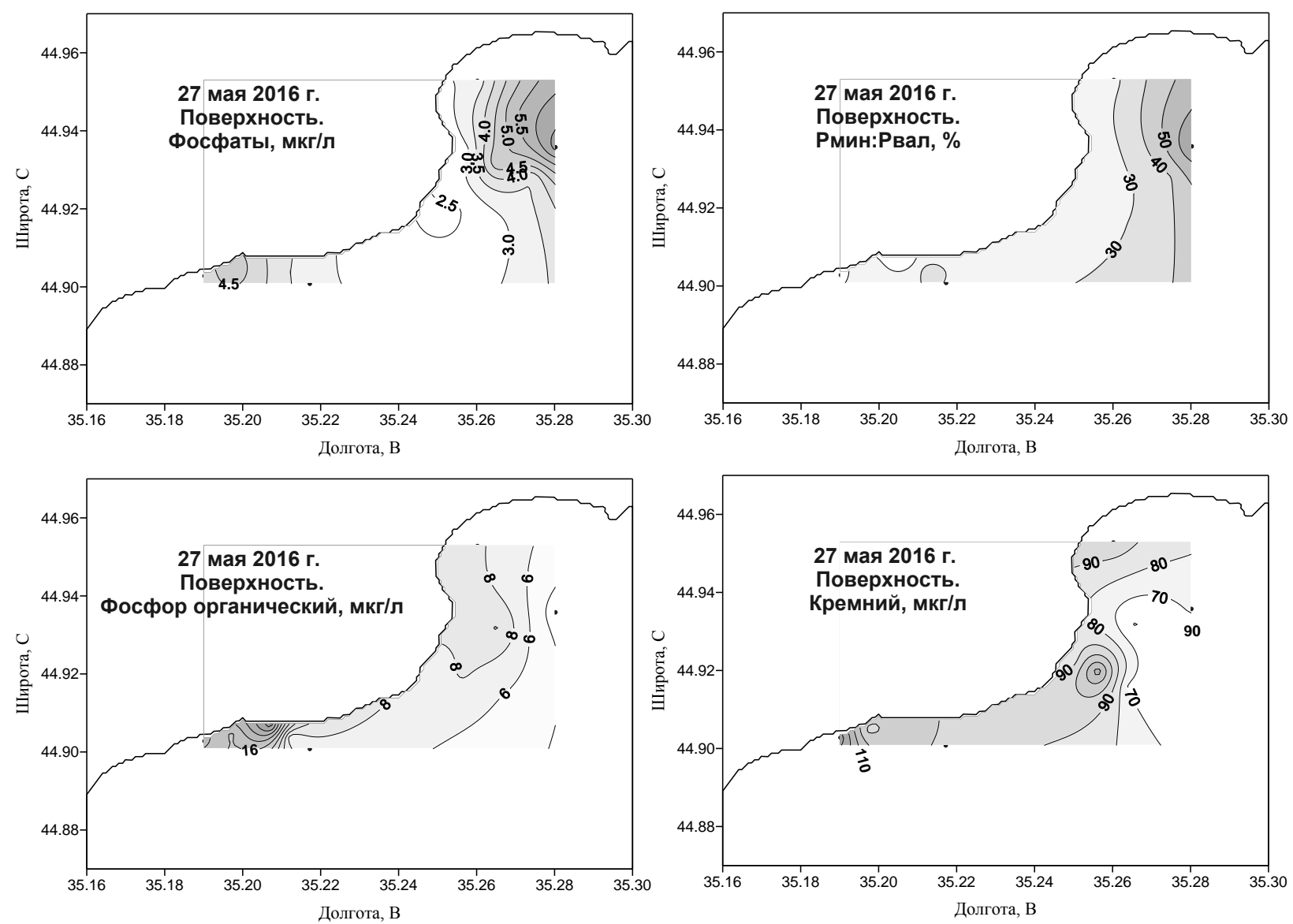

Рис. 5. Распределение гидрохимических показателей на поверхности 27 мая 2016 г.

Распределение кремния с востока на запад было аналогичным распределению фосфатов. Средняя величина кремния для поверхности Коктебельской бухты (88 мкг/л) была выше средней для поверхности Карадага (82 мкг/), без учета района, находящегося под влиянием хозбытового стока. Величины процентного отношения минеральной формы фосфора к валовой Рмин: Рвал изменялись в пределах от 13.4 до 69.8\%. Для семи станций из 14 получены низкие $(<30 \%)$ величины отношения Рмин: Рвал, что свидетельсвует о влиянии азовоморских вод ровно на $1 / 2$ исследованной акватории. Причем, распределение величин отношения Рмин: Робщ по акватории имеет пятнистый характер.

Фитопланктон. В планктоне исследуемого района зарегистрировано 59 видов микроводорослей (в мае - 38, в сентябре - 46), относящихся к 41 роду и 8 отделам. Обнаружено диатомовых водорослей 18 видов, динофитовых - 30, золотистых - 7, цианобактерий -2 , зеленых и эвгленовых - по 1.

В мае численность фитопланктона варьировала от 58 до 486 млн. кл. м $^{-3}$, биомасса

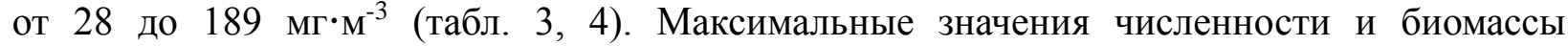
зафиксированы на поверхности станции м. Мальчин (ст. 1). На всех станциях доминировали диатомовые рода Pseudo-nitzshia spp. и гаптофитовая Emiliania huxlei, их численность составляла 32 - 68 и $13-61 \%$ от суммарной соответственно. Цианобактерии отмечены только в бухте Сердоликовой (ст. 4), где их численность составила 50\% от суммарной. Численность динофитовых не превышала $6.3 \%$, доминировала по численности Gymnodinium wulfii, по биомассе - крупноклеточные виды рода Ceratium. 
Таблица 3.

Численность $\left(N_{c y м}\right)$ (млн кл. $\left.\mathbf{M}^{-3}\right)$ основных групп и суммарного фитопланктона в прибрежных водах Карадага в мае и сентябре 2016 г.

\begin{tabular}{|c|c|c|c|c|c|c|c|c|}
\hline $\begin{array}{c}\text { № } \\
\text { ст }\end{array}$ & Станция & $N_{\text {сум. }}$ & $\begin{array}{c}\text { Bacillario- } \\
\text { phyta }\end{array}$ & Dino-phyta & $\begin{array}{c}\text { Haptophyta }+ \\
\text { Ochrophyta }\end{array}$ & $\begin{array}{c}\text { Chloro- } \\
\text { phyta }\end{array}$ & $\begin{array}{c}\text { Cyano- } \\
\text { procariota }\end{array}$ & $\begin{array}{c}\text { Euglenop } \\
\text { hyta }\end{array}$ \\
\hline \multicolumn{8}{|c|}{ май } \\
\hline 13 & Коктебель & 172.61 & 111.47 & 3.59 & 57.50 & 0.05 & 0 & 0 \\
\hline 1 & Мальчин & 486.00 & 216.23 & 8.33 & 252.45 & 0 & 0 & 9.00 \\
\hline 4 & Сердолик. & 141.28 & 44.80 & 0.44 & 25.64 & 0 & 70.40 & 0 \\
\hline 7 & Биостанц. & 220.01 & 149.19 & 13.93 & 56.89 & 0 & 0 & 0 \\
\hline 22 & Сток реки & 100.80 & 68.63 & 3.33 & 28.85 & 0 & 0 & 0 \\
\hline 21 & Очистные & 58.74 & 21.60 & 1.05 & 36.09 & 0 & 0 & 0 \\
\hline \multicolumn{7}{|c|}{ сентябрь } \\
\hline 13 & Коктебель & 3.11 & 1.43 & 1.26 & 0.32 & 0 & 0.10 & 0 \\
\hline 1 & Мальчин & 78.68 & 77.33 & 0.97 & 0.29 & 0 & 0.09 & 0 \\
\hline 4 & Сердолик. & 1.18 & 0.51 & 0.38 & 0.22 & 0 & 0.07 & 0 \\
\hline 7 & Биостанц. & 61.34 & 60.45 & 0.67 & 0.22 & 0 & 0 & 0 \\
\hline 22 & Сток реки & 30.41 & 0.40 & 0.31 & 0.12 & 0 & 29.58 & 0 \\
\hline 21 & Очистные & 16.05 & 15.24 & 0.71 & 0.07 & 0 & 0.04 & 0 \\
\hline
\end{tabular}

Таблица 4.

Биомасса $\left(\boldsymbol{B}_{\text {сум. }}\right)\left(\right.$ мг· $\left.\mathbf{M}^{-3}\right)$ основных групп и суммарного фитопланктона в прибрежных водах Карадага в мае и сентябре 2016 г.

\begin{tabular}{|c|c|c|c|c|c|c|c|c|}
\hline $\begin{array}{l}\text { № } \\
\text { ст }\end{array}$ & Станция & $B_{c y n}$. & $\begin{array}{c}\text { Bacillario- } \\
\text { phyta }\end{array}$ & Dinophyta & $\begin{array}{c}\text { Haptophyta + } \\
\text { Ochrophyta }\end{array}$ & $\begin{array}{l}\text { Chloro- } \\
\text { phyta }\end{array}$ & $\begin{array}{c}\text { Cyano- } \\
\text { procariota }\end{array}$ & $\begin{array}{c}\text { Eugleno } \\
\text { phyta }\end{array}$ \\
\hline \multicolumn{9}{|c|}{ май } \\
\hline 13 & Коктебель & 75.74 & 23.63 & 24.34 & 26.81 & 0.96 & 0 & 0 \\
\hline 1 & Мальчин & 189.61 & 79.45 & 31.05 & 67.79 & 0 & 0 & 11.31 \\
\hline 4 & Сердолик. & 31.85 & 16.47 & 0.72 & 10.06 & 0 & 4.61 & 0 \\
\hline 7 & Биостанц. & 170.59 & 55.09 & 63.48 & 52.02 & 0 & 0 & 0 \\
\hline 21 & Сток реки & 49.28 & 26.94 & 11.09 & 11.24 & 0 & 0 & 0 \\
\hline 22 & Очистные & 28.52 & 7.94 & 6.42 & 14.16 & 0 & 0 & 0 \\
\hline \multicolumn{9}{|c|}{ сентябрь } \\
\hline 13 & Коктебель & 40.55 & 29.77 & 9.05 & 1.57 & 0 & 0.16 & 0 \\
\hline 1 & Мальчин & 73.42 & 67.60 & 4.44 & 1.23 & 0 & 0.16 & 0 \\
\hline 4 & Сердолик. & 20.41 & 13.07 & 6.23 & 0.98 & 0 & 0.13 & 0 \\
\hline 7 & Биостанц. & 83.42 & 77.26 & 5.18 & 0.98 & 0 & 0 & 0 \\
\hline 21 & Сток реки & 19.62 & 17.72 & 0.96 & 0.52 & 0 & 0.42 & 0 \\
\hline 22 & Очистные & 35.47 & 32.93 & 2.12 & 0.36 & 0 & 0.06 & 0 \\
\hline
\end{tabular}

Меропланктон. Личинки донных беспозвоночных, обнаруженные в пробах, относились к следующим таксонам: Hydrozoa, Bivalvia, Gastropoda, Polychaeta, Cirripedia, Decapoda. В мае, при температуре воды $16.0^{\circ}-16.5^{\circ} \mathrm{C}$ численность меропланктона у мыса

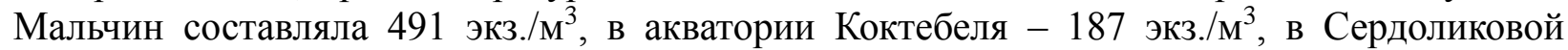
бухте - 150 экз./ $\mathrm{M}^{3}$, а в районе причала Биостанции не превышала 24 экз./ $\mathrm{M}^{3}$ (рис. 6). Двустворчатые моллюски были представлены личинками мидии Mytilus galloprovincialis Lamarck, 1819, находящимися на разных стадиях развития. Их численность колебалась от 9 до 83 экз./м³. У берегов Крыма M. galloprovincialis начинают массово размножатся в апреле при прогреве воды до $10^{\circ}-11^{\circ} \mathrm{C}$. Можно предположить, что к концу мая большая часть личинок уже осела. Единично в планктоне встречались великонхи мии Mya arenaria Linnaeus, 1758, их максимальное количество - 34 экз./ $\mathrm{M}^{3}$ зарегистрировано у мыса Мальчин. Этот моллюск-вселенец уже был ранее отмечен у берегов Карадага. Мия нерестится при температуре воды около $17^{\circ}-18^{\circ} \mathrm{C}$, личинки встречаются только в конце мая - начале июня, что подтверждается полученными нами данными. 


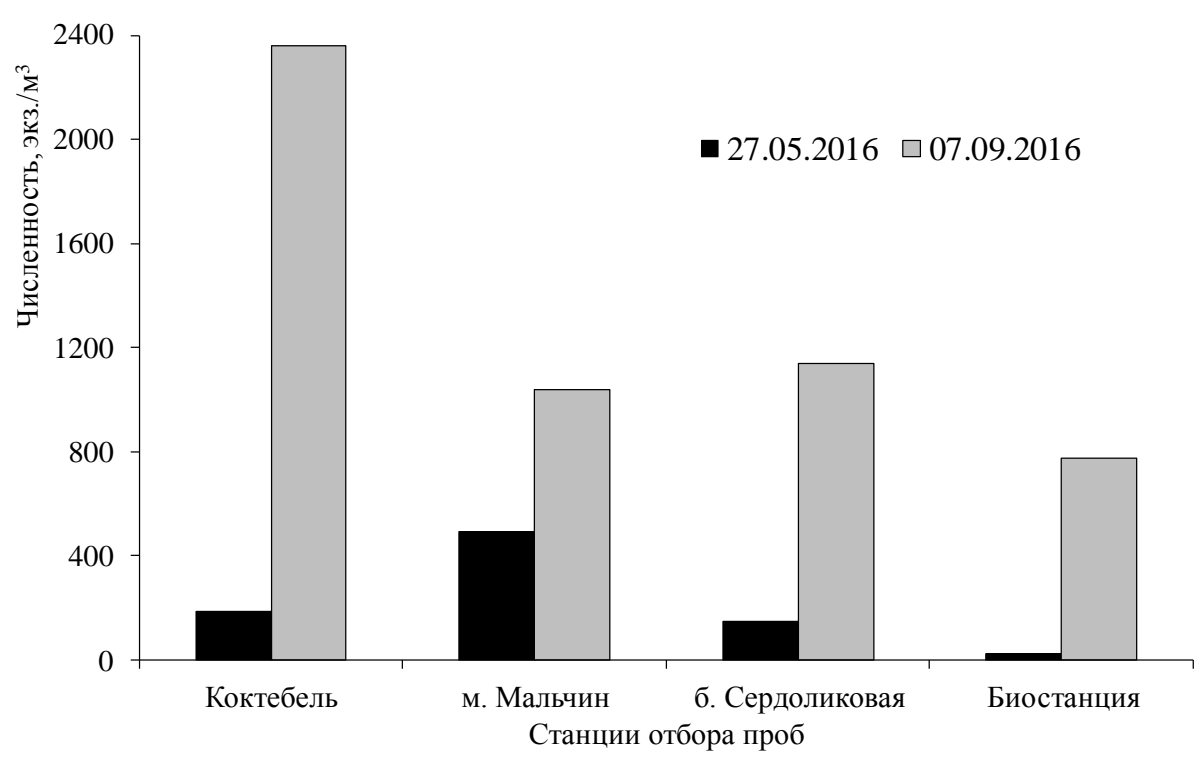

Рис. 6 Численность меропланктона в прибрежной зоне Карадага.

Численность велигеров брюхоногих моллюсков семейства Rissoidae изменялась от

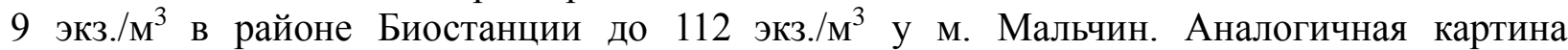
наблюдалась нами и в мае 2004 г.: численность личинок Gastropoda изменялась от 5 экз./м ${ }^{3}$ (Биостанция) до 184 экз./ $\mathrm{M}^{3}$ (стена Лагорио) (Ковригина и др.,2007). Низкие значения численности личинок обусловлены тем, что у берегов Крыма массовые виды брюхоногих моллюсков размножаются при достаточном прогреве воды. Их велигеры доминируют в меропланктоне в летние месяцы (Чухчин, 1984).

Максимальное количество личинок многощетинковых червей (130 экз./ м $\left.^{3}\right)$ также было отмечено у м. Мальчин. В планктоне преобладали представители семейства Spionidae (Malacoceros fuliginosus (Claparède, 1870), Spio decorata Bobretzky, 1870), нектохеты Harmothoe reticulata (Claparede, 1879) и Magelona rosea Moore, 1907. Единично отмечены трохофоры Nereididae и Pholoe inornata Johnston, 1839. Все виды полихет, личинки которых обнаружены нами в планктоне, указаны ранее для фауны Карадага (Мурина, Киселева, Костенко, 2004). Науплиусы усоногого рака Amphibalanus improvisus Darwin, 1854 встречались вдоль всего побережья, их численность увеличивалась от 2 экз./м ${ }^{3}$ у Биостанции до 132 экз./ $\mathbf{M}^{3}$ - у м. Мальчин. Единично встречались пилидии Nemertea (4 экз./ $\mathbf{m}^{3}$ ). Личинки десятиногих раков в майских пробах отмечены не были, так как в Черном море большинство видов Decapoda начинают размножаться только в теплый сезон года при прогреве воды выше $18^{\circ}-19^{\circ} \mathrm{C}$, а их личинки встречаются в планктоне с июня по октябрь (Макаров, 2004).

Съемка 7 сентября 2016 г.

По данным съемки можно говорить о полной поверхностной гомотермии исследуемого района. Однородное распределение температуры находилось в диапазоне $24.8^{\circ}-25.0^{\circ} \mathrm{C}$ (рис. 7 , табл. 5). Эти значения являются аномально высокими для сентября. Они почти на $3^{\circ} \mathrm{C}$ выше среднемноголетних показателей и на $0.6^{\circ} \mathrm{C}$ максимальных величин, ранее зафиксированных нами (Трощенко, Субботин, Ерёмин, 2015). Несмотря на узкий диапазон изменчивости, в районе Коктебельской бухты и м. Мальчин проявляется слабовыраженный круговорот, что может отразиться на распределении других характеристик. Вертикальное распределение температуры также было однородным, т.е. почти всю толщу вод занимал ВКС. Только на мористых станциях, с глубиной около 30 м, у самого дна был обнаружен СТ. 


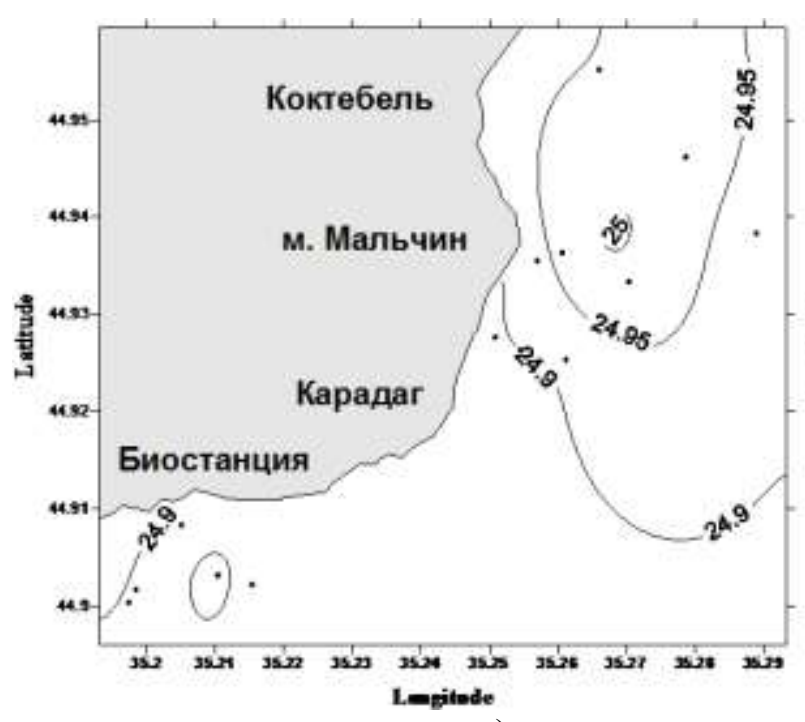

a)

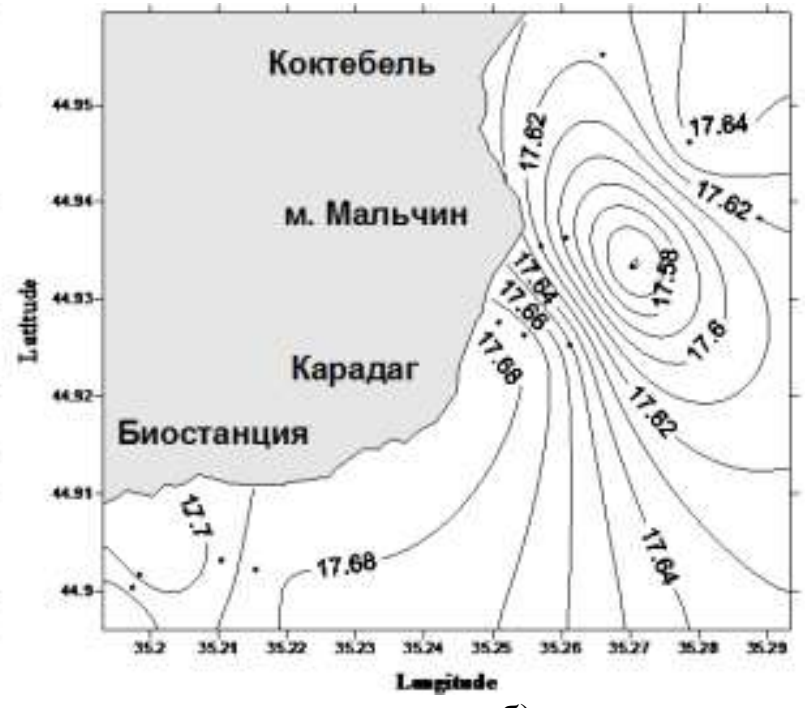

б)

Рис. 7. Распределение поверхностной температуры воды (а) и солёности (б) 7 сентября 2016 г.

Таблица 5.

Распределение гидролого-гидрохимических показателей на Карадагском взморье

\begin{tabular}{|c|c|c|c|c|c|c|c|c|c|c|c|c|c|c|}
\hline \multicolumn{15}{|c|}{ Карадагское взморье. Коктебель. Разрезы. 7 сентября 2016 г. } \\
\hline № & $\mathrm{H}$, & $\mathrm{T}$, & $\mathrm{S}$, & & 2, & БПК ${ }_{5}$, & $\mathrm{NO}_{2}$ & $\mathrm{NO}_{3}$, & $\mathrm{NH}_{4}$, & $\mathrm{PO}_{4}$, & $\mathrm{Si}$ & Рорг & Nорг & \multirow{2}{*}{$\begin{array}{l}\text { Окис } \\
\text { мгО/л }\end{array}$} \\
\hline ст & M & ${ }^{\circ} \mathrm{C}$ & $\% 0$ & Мл/л & $\%$ & мг/л & \multicolumn{7}{|c|}{ мкг/л } & \\
\hline 13 & 0 & 24,95 & 17,62 & 5,28 & 101,0 & 1,57 & 2,3 & 20,8 & 29,3 & 14,5 & 76,5 & 12,8 & 518,7 & 2,82 \\
\hline 13 & 10 & 24,90 & 17,60 & 5,43 & 103,8 & & 1,1 & 13,9 & & 10,0 & 55,4 & & & \\
\hline 12 & 0 & 25,00 & 17,65 & 5,46 & 104,6 & 0,86 & 1,2 & 25,9 & 57,3 & 15,1 & 69,9 & 2,2 & 450,3 & 3,09 \\
\hline 12 & 20 & 24,90 & 17,65 & 5,71 & 109,2 & & 0,5 & 24,2 & & 10,6 & 51,5 & & & \\
\hline 11 & 0 & 24,90 & 17,62 & 5,63 & 107,6 & 1,63 & 0,9 & 19,3 & 39,3 & 1,7 & 58,1 & 11,7 & 458,9 & 3,69 \\
\hline 11 & 30 & 23,90 & 17,66 & 4,81 & 90,2 & & & 8,3 & & & & & & \\
\hline 2 & 0 & 25,00 & 17,54 & 5,53 & 105,7 & 1,90 & 1,8 & 18,4 & 17,6 & 11,7 & 55,4 & 3,3 & 407,7 & 3,24 \\
\hline 2 & 29 & 24,40 & 17,73 & 5,61 & 106,4 & & 2,6 & 15,1 & & 19,5 & 70,6 & & & \\
\hline 3 & 0 & 25,90 & 17,59 & 5,88 & 114,3 & 1,65 & 1,2 & 8,3 & 41,6 & 10,0 & 44,2 & 4,5 & 418,7 & 4,11 \\
\hline 3 & 20 & 24,30 & 17,69 & 5,58 & 105,5 & & 0,8 & 9,9 & & 3,9 & 74,6 & & & \\
\hline 1 & 0 & 24,90 & 17,62 & 5,61 & 107,2 & 1,38 & 3,0 & 16,7 & 58,3 & 19,0 & 59,4 & 14,5 & 622,6 & 4,13 \\
\hline 1 & 12 & 24,60 & 17,67 & 5,56 & 105,7 & & 4,8 & 10,8 & & 19,0 & 132,0 & & & \\
\hline 4 & 0 & 24,90 & 17,68 & 5,59 & 106,9 & 1,96 & 1,1 & 26,7 & 39,0 & 12,8 & 92,4 & 7,8 & 528,6 & 3,90 \\
\hline 4 & 10 & 24,60 & 17,69 & 5,49 & 104,5 & & 1,0 & 22,8 & & 7,8 & 76,5 & & & \\
\hline 19 & 0 & 24,90 & 17,68 & 5,47 & 104,6 & 1,24 & 1,2 & 8,6 & & 8,4 & 85,8 & & & \\
\hline 19 & 20 & 24,60 & 17,76 & 5,52 & 105,0 & & 1,3 & 12,4 & & 11,7 & 41,6 & & & \\
\hline 20 & 0 & 24,90 & 17,66 & 5,63 & 107,6 & 1,66 & 0,9 & 18,7 & 52,6 & 11,2 & 52,8 & 0,0 & 442,1 & 2,87 \\
\hline 20 & 30 & 23,70 & 17,70 & 5,63 & 105,3 & & 1,6 & 10,3 & & 10,0 & 71,9 & & & \\
\hline 6 & 0 & 24,90 & 17,68 & 5,57 & 106,5 & 1,51 & 1,6 & 29,4 & 32,6 & 10,0 & 47,5 & 3,3 & 410,3 & 3,83 \\
\hline 6 & 30 & 22,80 & 17,71 & 5,78 & 106,5 & & 1,6 & 11,2 & & 17,9 & 99,0 & & & \\
\hline 5 & 0 & 24,80 & 17,70 & 5,45 & 104,0 & 1,14 & 0,6 & 17,4 & 24,3 & 7,8 & 61,4 & 3,9 & 459,8 & 3,74 \\
\hline 5 & 20 & 23,70 & 17,70 & 5,47 & 102,3 & & 0,7 & 20,8 & & 6,7 & 96,3 & & & \\
\hline 7 & 0 & 24,90 & 17,70 & 5,38 & 102,9 & 0,88 & 1,6 & 23,6 & 26,6 & 8,4 & 65,3 & 8,9 & 596,2 & 3,42 \\
\hline 7 & 8 & 24,50 & 17,70 & 5,47 & 103,9 & & 0,4 & 0,1 & & 5,6 & 81,1 & & & \\
\hline 21 & 0 & 24,90 & 17,68 & 5,36 & 102,4 & 1,59 & 1,8 & 39,8 & 53,9 & 13,4 & 148,4 & 8,4 & 479,6 & 3,64 \\
\hline 21 & 3 & 24,90 & 17,70 & 5,34 & 102,1 & & 0,9 & 15,1 & & 8,4 & 62,0 & & & \\
\hline 22 & 0 & 24,90 & 17,72 & 5,46 & 104,4 & 1,48 & 1,2 & 17,7 & 35,0 & 8,4 & 163,6 & 11,2 & 622,5 & \\
\hline 22 & 4 & 24,90 & 17,72 & 5,76 & 110,2 & & & 14,6 & & & 130,6 & & & \\
\hline
\end{tabular}


Диапазон изменчивости поверхностной солёности был несколько шире, чем весной и составлял 17.54-17.72\%. В целом, солёность закономерно повышалась с востока на запад. В районе Коктебельской бухты и м. Мальчин, как и по температуре, отмечался слабовыраженный круговорот. Судя по значениям температуры и солёности в его центре, он был антициклоническим. С глубиной солёность постепенно увеличивалась. Однако на всех прибрежных станциях увеличения солёности с глубиной или совсем не было, или оно было минимальным (табл. 5), что может говорить о проявлениях субмаринной разгрузки, либо о хорошем ветро-волновом перемешивании. Однако в день проведения съёмки ветер был умеренным, а волнение не превышало 1 балла.

Растворенный кислород на всей акватории так же, как и в мае 2016 г., имел высокие значения. Величины насыщения превышали нормальное на 1-14\%. Исключение составила только ст. 11, где в придонном слое отмечено резкое понижение содержания кислорода (4.81 мл/л и 90.2\% насыщение) по сравнению с поверхностью (5.63 мл/л и 107\%). Повидимому, имело место субмаринная разгрузка пресных вод.

В целом по съемке величины минеральных форм азота и фосфора были повышены. Влияние азовоморских вод по отношению Рмин: Рвал отмечено только на одной станции, где оно составляло $13 \%$. На остальной акватории величины этого отношения изменялись от 43 до 87\%. Их значения превышали $30 \%$, что свидетельствует о влиянии черноморских вод практически на всей исследуемой акватории. Подтверждением этому так же служат величины биогенных веществ, таких как кремний и фосфаты. Средняя величина кремния (68 мкг/л) в Коктебельской бухте была ниже, чем на акватории Карадага (80 мкг/л). Средняя по величинам фосфатов, также как и кремния, была на 0.6 мкг/л ниже, что свидетельствует о влиянии черноморских вод.

Влияние хозбытовых вод так же, как и в майской съемке, зафиксировано на поверхности прибрежных станций 7, 21 и 22 по высоким концентрациям биогенных веществ. Так, максимальные величины нитратов (40 мкг/л) и кремния (148 мкг/л), а также высокая концентрация аммонийного азота (54 мкг/л) отмечены на ст. 21. На ст. 22 обнаружено максимальное содержание азота органического (622 мкг/л). На ст. 7 отмечены кроме высокого содержания азота органического и высокие концентрации минеральных форм азота (табл. 5). На поверхности ст. 1 в районе м. Мальчин обнаружены максимальные величины фосфора органического (14.5 мкг/л), азота органического (622 мкг/л) и окисляемости (4.13 мгО/л), превышающей ПДК.

Используя величины полученной нами перманганатной окисляемости и коэффициент 0.34 (Скопинцев, 1975) было рассчитано содержание органического углерода (Сров) на поверхности прибрежной зоны Карадага и Коктебельской бухты (табл. 6).

Таблица 6.

Содержание растворенного органического вещества (Сров) 07.09.2016 г.

\begin{tabular}{|c|c|c|c|c|c|}
\hline N станции & $\begin{array}{c}\text { Окисляемость, } \\
\text { мг О/л }\end{array}$ & $\begin{array}{c}\text { Сров, } \\
\text { мг С/л }\end{array}$ & N станции & $\begin{array}{c}\text { Окисляемость, } \\
\text { мгО/л }\end{array}$ & $\begin{array}{c}\text { Сров, } \\
\text { мг С/л }\end{array}$ \\
\hline 13 & 2.82 & 8.29 & 19 & - & - \\
\hline 12 & 3.09 & 9.09 & 20 & 2.87 & 8.44 \\
\hline 11 & 3.69 & 10.85 & 6 & 3.83 & 11.2 \\
\hline 2 & 3.24 & 9.53 & 5 & 3.74 & 11.0 \\
\hline 3 & 4.11 & 12.09 & 7 & 3.42 & 10.0 \\
\hline 1 & 4.13 & 12.15 & 21 & 2.64 & 10.7 \\
\hline 4 & 3.90 & 11.47 & 22 & - & - \\
\hline
\end{tabular}

Диапазон колебаний величин Сров в сентябре составлял 8.29-12.15 мгС/л. Максимум зафиксирован в районе м. Мальчин (прибрежная ст. 1), минимум - в районе 
бухты Коктебель (прибрежная ст. 13). По сравнению с 2004 г. (начало исследований) на повторяющихся станциях $(1,4$ и 7$)$ величины Сров в настоящее время были несколько ниже. Так, на ст.1 в 2016 г. содержание Сров составило 12.15 по сравнению с 13.18 мг С/л в 2004 г. На ст.4 - 11.47 против 12.24 мгС/л и на ст.7 - 10.06 по сравнению с 14.12 мгС/л. Полученные в настоящее время величины Сров показали, что накопления органического вещества за исследуемый нами период не произошло.

В наиболее подверженных загрязнению районах (Курортное, Очистные сооружения и Биостанция) в сентябре 2004 г. наблюдалось увеличение гибели пелагических личинок донных беспозвоночных. Отмечено, что жизнеспособность меропланктона составляла 70\% (Ковригина и др., 2007).

Величины БПК5 изменялись в пределах 0.86-1.96/мг/л и не превышали ПДК. Средняя по съемке величина составляла 1.46 мг/л. Коэффициент загрязнения Кз, характеризующий состояние загрязненности акватории имел пределы изменчивости от 0.26 до 0.57 и не превышал 1. Поэтому всю акваторию в сентябре 2016 г. мы можем, также как и в мае, считать незагрязненной (рис. 8).
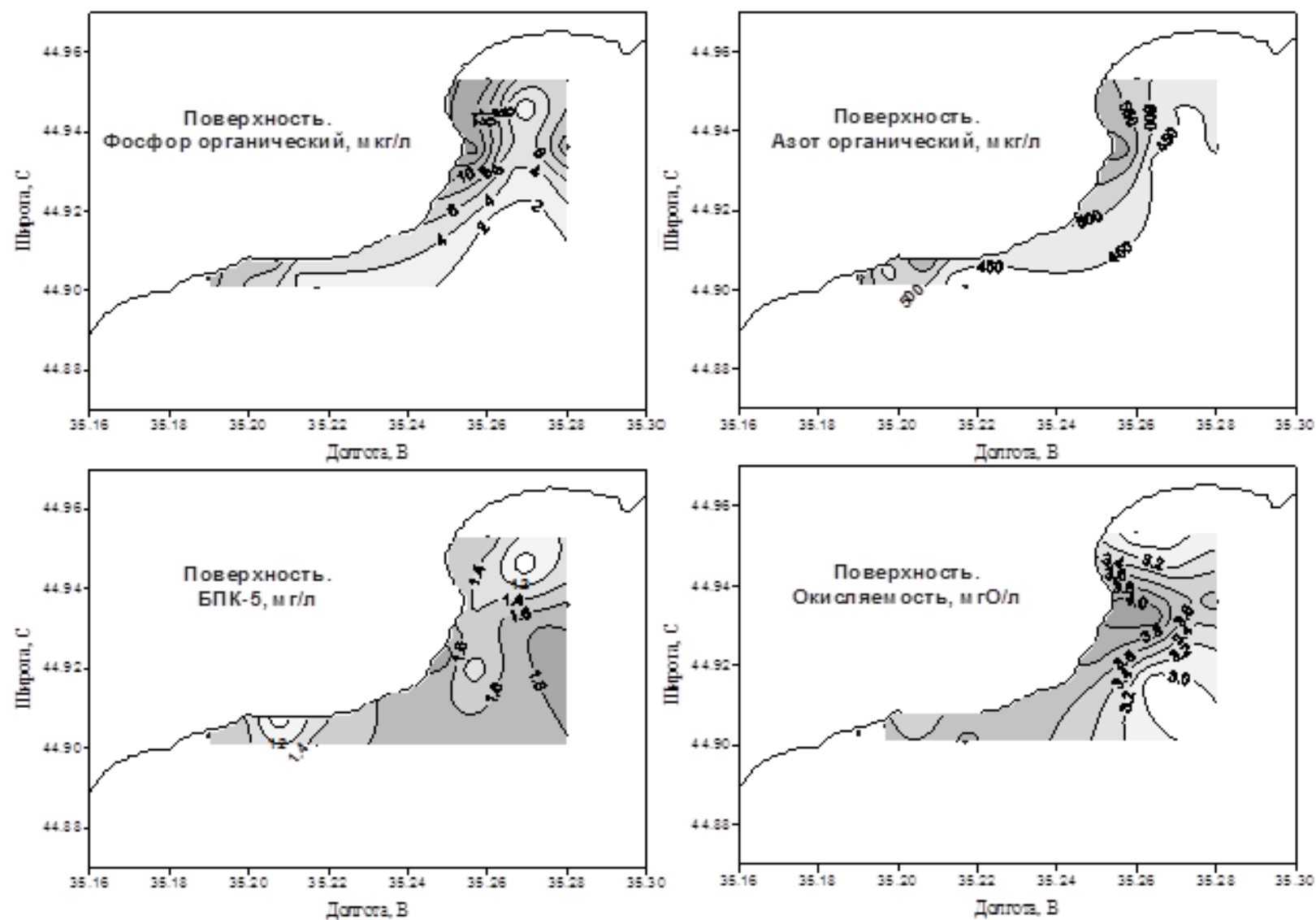

Рис. 8. Распределение органических форм азота и фосфора (мкг/л), БПК окисляемости (мгО/л) 7 сентября 2016 г.

О биогенной обеспеченности вод свидетельствует отношение суммарного минерального азота к фосфору в атомном выражении ( $\sum$ N/P). Принято считать, что если это отношение больше средней величины 15 , то лимитирующим будет содержание фосфатов, а если меньше 15, то задерживать развитие фитопланктона будет недостаток азота. Данные, полученные для Карадагского взморья в сентябре, приведены ниже.

Первые три станции $\left(13,1\right.$ и 4) имеют $\sum \mathrm{N} / \mathrm{P}$ меньше 15 , поэтому в этих районах 
задерживать развитие фитопланктона будет недостаток азота. Остальные районы, начиная с Биостанции, имеют $\sum$ N/P больше 15 и для них лимитирующим фактором является фосфор (табл. 6).

Таблица 6.

Концентрации неорганических форм азота и фосфора и их отношение на Карадагском взморье (07.09.2016 г.)

\begin{tabular}{|c|c|c|c|c|c|c|c|}
\hline \multirow{2}{*}{ Районы } & \multirow{2}{*}{$\begin{array}{c}\text { № } \\
\text { станций }\end{array}$} & \multicolumn{7}{|c|}{ Концентрация, мкг-ат/л } & \multirow{2}{*}{$\sum \mathrm{N} / \mathrm{P}$} \\
\cline { 3 - 7 } & & $\mathrm{NO}_{2}{ }^{-}$ & $\mathrm{NO}_{3}{ }^{-}$ & $\mathrm{NH}_{4}{ }^{+}$ & $\sum$ Nмин & $\mathrm{PO}_{4}{ }^{3-}$ & \\
\hline Коктебель & 13 & 0.16 & 1.48 & 2.09 & 3.73 & 0.47 & 7.94 \\
\hline Мальчин & 1 & 0.21 & 1.19 & 4.16 & 5.56 & 0.61 & 9.11 \\
\hline Сердоликовая & 4 & 0.08 & 1.91 & 2.78 & 4.77 & 0.41 & 11.63 \\
\hline Биостанция & 7 & 0.11 & 1.68 & 19.0 & 20.79 & 0.27 & 77.0 \\
\hline Сток р. Отузка & 22 & 0.13 & 2.84 & 3.85 & 6.82 & 0.43 & 15.86 \\
\hline Очистные & 21 & 0.08 & 22.4 & 2.5 & 24.98 & 0.27 & 92.52 \\
\hline
\end{tabular}

Фитопланктон. В сентябре суммарные значения численности фитопланктона (178 млн кл. $\mathrm{M}^{-3}$ ) на всех станциях были значительно ниже, чем в мае, а видовое разнообразие - выше. Наибольшая численность и биомасса фитопланктона зарегистрирована на станциях 1 и 7 (м. Мальчин и Биостанция) (табл. 3,4). На станциях 1, 7, 22 (м. Мальчин, Биостанция и Очистные) по численности доминировала диатомовая Leptocylindrus danicus, еe вклад составлял 55, 76 и 88\% от суммарной численности соответственно. В бухте Коктебель (ст. 13) основной вклад в численность вносили диатомовые Pseudosolenia calcar-avis и Skeletonema costatum, динофлагеллята G. wulffii (15, 12 и 16\%). В б. Сердоликовой (ст. 4) группу доминирующих видов составили диатомовые рода Pseudo-nitzshia spp., Ps. calcar-avis, гаптофитовая Oolithotus fragilis, динофитовая Ceratium furca. В районе стока реки Отузки (ст. 21) 97\% суммарной численности приходилось на цианобактерию Microcystis sp. Значительный вклад в состав биомассы на всех станциях вносила крупноклеточная диатомея P. calcar-avis $(61-90 \%)$, а на ст. 13 и 4 (Коктебель и б. Сердоликовая) ей сопутствовала крупная динофитовая $C$. furca $(11-16 \%)$.

Таким образом, суммарные значения численности и биомассы фитопланктона в мае были выше, чем в сентябре. В мае по численности доминировали мелкоклеточные виды диатомовых и гаптофитовых водорослей, тогда как в сентябре руководящей группой были диатомовые, при этом значительную долю биомассы составлял крупноклеточный вид P. calcar-avis. Увеличение численности цианобактерий отмечено в мае на ст. 4 (б. Сердоликовая), в сентябре - на ст. 21 (сток реки Отузки).

В мае отмечена обратная связь между значениями суммарной численности фитопланктона $\left(N_{c y м}\right)$ и биогенными веществами $\left(\mathrm{NO}_{3}, \mathrm{PO}_{4}, \mathrm{Si}\right)$. В сентябре при снижении общей численности планктонных микроводорослей и доминировании P. calcar-avis (по биомассе) отмечена связь только между суммарной биомассой $\left(B_{c y м}\right)$ и кремнием.

Меропланктон. В сентябре при температуре воды $24.90^{\circ}-24.95^{\circ} \mathrm{C}$ максимальная численность личинок донных беспозвоночных зарегистрирована в районе Коктебеля $\left(2360\right.$ экз. $\left./ \mathrm{M}^{3}\right)$. У мыса Мальчин она составляла 1040 экз. $\mathrm{M}^{3}$, в бухте Сердоликовая 1141 экз./ $\mathrm{M}^{3}$. Минимальная численность - 774 экз./ $\mathrm{M}^{3}$, как и в мае, отмечена у причала Биостанции (рис. 6). На всей исследуемой акватории по численности преобладали великонхи двустворчатых моллюсков (Mytilaster lineatus (Gmelin, 1791), Anadara kagoshimensis (Tokunaga, 1906), Chamelea gallina (Linnaeus, 1758)). Численность личинок Bivalvia в бухте Коктебель достигала 1125 экз./ $\mathrm{m}^{3}$, в акватории заповедника изменялась от 271 до 645 экз./м³ . Единично встречались великонхи корабельного червя Teredo navalis 
Linnaeus, 1758. Количество велигеров Gastropoda уменьшалось от бухты Коктебельской $\left(412\right.$ экз./ $\left.\mathrm{M}^{3}\right)$ до Биостанции (99 экз./ $\left.\mathrm{M}^{3}\right)$. В прибрежных водах заповедника оно составляло 330 экз./ $\mathrm{M}^{3}$. В конце июля - начале августа у берегов Крыма начинает размножаться Rapana venosa (Valenciennes, 1846), велигеры встречаются в планктоне до октября. Во время съемки отмечено увеличение численности личинок $R$. venosa - до 41 экз./ $\mathrm{M}^{3}$, тогда как в предыдущие годы их численность не превышала 10 - 12 экз./ $\mathrm{M}^{3}$.

Личинки Polychaeta в акватории заповедника распределились относительно равномерно - от 252 до 281 экз./ $\mathrm{M}^{3}$, и лишь в районе Коктебеля их численность была существенно выше - 478 экз./м³. В планктоне преобладали нектохеты Nephtys hombergii Savigny, 1818, Polydora cornuta Bosc, 1802, Prionospio sp. Единично встречались личинки Lysidice ninetta Aud. et M. Edw., 1834 и предстаители семейства Phyllodocidae. Количество личинок усоногих раков было незначительно - от 4 до 29 экз./ ${ }^{3}$, причем большая часть из них находились на поздних стадиях и стадии циприса. Можно предположить, что в этот период произошло массовое оседание усоногих раков на твердые субстраты. В пробах существенно увеличилось количество личинок десятиногих раков. В прибрежных водах

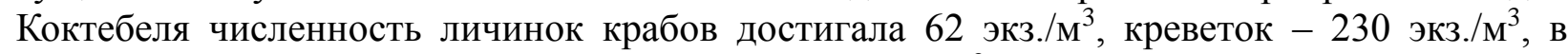
акватории заповедника изменялась от 34 до 102 экз./ ${ }^{3}$. На всей исследуемой акватории единично встречались личинки мшанок, пилидии немертин и актинотрохи Phoronis.

Количественные показатели меропланктона во время съемок были существенно выше в акватории поселка Коктебель и мыса Мальчин. В районе Биостанции численность личинок донных беспозвоночных была ниже как в мае, так и в сентябре. Можно предположить, что на распределение меропланктона в районе исследования влияют гидродинамика вод и их гидрохимические характеристики. Увеличение численности личинок многощетинковых червей семейства Spionidae, отмеченное в районе Биостанции, может косвенно свидетельствовать о заилении грунта в данном районе. Здесь же отмечено снижение видового состава и общей численности меропланктона, что может свидетельствовать о негативном влиянии хозяйственно-бытовых стоков на жизнедеятельность гидробионтов. Остальные районы относительно стабильны по гидрохимическим характеристикам и в меньшей степени подвержены антропогенному воздействию, что сказывается и на состоянии меропланктона - видовое разнообразие и количество пелагических личинок беспозвоночных в этих районах несколько выше.

\section{Выводы}

В мае 2016 г. в районе м. Мальчин обнаружен слабовыраженный гидрологический фронт, а в сентябре в Коктебельской бухте и у м. Мальчин - антициклонический круговорот. Такие распределения термохалинных характеристик отразились на пространственной изменчивости других рассматриваемых показателей. Особенно хорошо это видно по распределению меропланктона.

Локальное загрязнение хозбытовыми водами в мае отмечено в Коктебельской бухте, в сентябре - в районе м. Мальчин. Оно прослеживалось по повышенным концентрациям биогенных веществ, БПК5 и окисляемости. Величины растворенного органического вещества, рассчитанные для 2016 г. показали, что накопления органического вещества за весь исследуемый нами период (2004 - 2016 гг.) не произошло. В загрязненных хозбытовыми стоками районах отмечено снижение численности меропланктона.

Влияние азовоморских вод в мае было слабым. Оно проявилось на 5 станциях из 14 по величинам отношения Рмин : Рвал, которое было ниже $30 \%$. В сентябре влияние азовоморских вод отмечено только на одной станции. На остальной акватории преобладали черноморские воды. 
Суммарные значения численности и биомассы фитопланктона в мае были выше, чем в сентябре: величины численности различались от 2-х раз до 2-х порядков, величины биомассы - от 2 до 3-х раз. В мае по численности доминировали мелкоклеточные виды диатомовых и гаптофитовых водорослей, тогда как в сентябре руководящей группой были крупноклеточные диатомовые.

Численность меропланктона в сентябре были значительно выше по сравнению с маем: в Коктебельской бухте - на порядок, у м. Мальчин - в 2 раза, в б. Сердоликовой - в 8 и в районе Биостанции - в 32 раза. В мае по численности в этих районах преобладали науплиусы усоногого рака A. improvisus, в сентябре - личинки моллюсков.

Учитывая увеличение антропогенной нагрузки на узкую прибрежную зону Карадага, значительные межгодовые колебания исследуемых характеристик, а также для выявления их трендов необходимо продолжение регулярных комплексных наблюдений в акватории природного заповедника и прилегающих к нему районах.

Авторы выражают благодарность всем участникам экспедиций и сотрудникам, помогавшим обрабатывать первичные данные (Бобко Н.И., Богдановой Т.А., Капранову С.В., Родионовой Н.Ю.), а также администрации Карадагской научной станции за предоставленную возможность проводить исследования на акватории заповедника.

\section{Список литературы}

1. Ковригина Н.П., Павлова Е.В., Мурина В.В., Лисицкая Е.В., Смирнова Ю.Д. Гидрохимическая характеристика и меропланктон прибрежных вод Карадага (2004 г.) // Экологическая безопасность прибрежной и шельфовой зон и комплексное использование ресурсов шельфа. - 2007. - Вып. 15. - С. 139-151.

2. Мурина В.В., Киселева Г.А., Костенко Н.С. Тип кольчатые черви. Многощетинковые черви - Polychaeta. // Карадаг. Гидробиологические исследования. Сборник научных трудов, посвященный 90-летию Карадагской научной станции им. Т.И. Вяземского и 25-летию Карадагского природного заповедника НАН Украины. Книга 2-я. Симферополь: СОНАТ, 2004. - С. 340-360.

3. Чухчин В.Д. Экология брюхоногих моллюсков Черного моря. - К: Наук. думка, 1984. $176 \mathrm{c.}$

4. Макаров Ю.Н. Десятиногие ракообразные. - К.: Наук. думка, 2004. - 430 с.

5. Методы гидрохимических исследований основных биогенных элементов. - М.: ВНИРО, 1988. - 119 с.

6. Методические указания № 30. - М.: Гидрометеоиздат, 1966. - 39 с.

7. Павлова E.B., Лисицкая E.B. Состояние зоопланктонных сообществ в прибрежных водах Карадагского природного заповедника (2002 - 2005 гг.). // Карадаг - 2009: сб. науч. тр., посвящ. 95-летию Карадагской науч. станции и 30-летию Карадагского природного заповедника НАН Украины. - Севастополь, 2009. - С. 292 - 312.

8. Руководство по гидрологическим работам в океанах и морях. - Л.: Гидрометеоиздат, 1977. $-725 \mathrm{c}$.

9. Скопинцеев Б.А. Формирование современного химического состава вод Черного моря. Л.: Гидрометеоиздат, 1975. - 335 с.

10. Трощенко О.А., Субботин А.А., Ерёмин И.Ю. Изменчивость параметров термохалинной структуры вод в прибрежной зоне Карадагского природного заповедника по данным многолетних наблюдений // 100 лет Карадагской научной станции им. Т.И. Вяземского: сборник научных трудов. - Симферополь: Н.Оріадна, 2015. - C.748-752. 
11. Ковригина Н.П., Трощеено О.А. Щуров С.В. Особенности пространственного распределения гидролого-гидрохимических показателей прибрежной акватории Карадага в современный период (2005 - 2006 гг.) // Карадаг - 2009: Сборник научных трудов, посвященных 95-летию Карадагской научной станции и 30-летию Карадагского природного заповедника Национальной академии наук Украины. - Севастополь: ЭКОСИ-Гидрофизика, 2009. - С. 446-461.

12. Костенко Н.С. Гидробиологические исследования на Карадаге (обзор) // 100 лет Карадагской научной станции им. Т.И.Вяземского: сборник научных трудов. Симферополь: Н. Оріанда, 2015. - С. 401-456.

13. Сеничева М.И., Поспелова Н.В. Сезонные и многолетние изменения фитопланктона в прибрежных водах Карадагского природного заповедника // 100 лет Карадагской научной станции им. Т.И. Вяземского: сборник научных трудов. - Симферополь: Н. Оріанда, 2015. C. $467-477$.

\section{HYDROLOGICAL-HYDROCHEMICAL AND HYDROBIOLOGICAL RESEARCH ON KARADAG SEASIDE DURING THE WARM SEASON OF 2016}

Kovrigina N.P., Lisitskaya E.V., Pospelova N.V., Troshchenko O.A., Eremin I.Y.

Kovalevsky Institute of Marine Biological Research, Russian Academy of Sciences, Sevastopol, Russian Federation, e-mail:, maricultura@mail.ru

The results of comprehensive research conducted in May and September 2016 in the coastal waters of the Karadag and Koktebel Bay were given. These were presented data on the thermohaline structure of waters, hydrochemical parameters (dissolved oxygen, oxidation, BOD5 and key nutrients), abundance and biomass of phytoplankton and meroplankton. It was shown that the thermohaline structure directly affects the distribution of hydrochemical and hydrobiological indicators. The presence of the Azov Sea water on the surface and the subaqual waters in the bottom layer of specified aquatic area were noted. It was determined the influence of domestic wastewater of settlements Koktebel and Kurortnoe on the distribution of hydrological and hydrochemical fields as well as on the state of phytoplankton and meroplankton. Comparison of the content of organic matter and the number of meroplankton that we obtained at the beginning of studies (2004) with data 2016 was carried out. It was demonstrated a correlation between the values of the total abundance and biomass of phytoplankton and nutrients.

Key words: hydrological and hydrochemical structure, nutrients, phytoplankton, meroplankton, Karadag coastal area, the Black sea. 